\title{
Islet amyloid polypeptide/amylin messenger RNA and protein expression in human insulinomas in relation to amyloid formation
}

\author{
K L van Hulst ${ }^{1,2}$, C Oosterwijk ${ }^{1,3}$, W Born ${ }^{4}$, Th M Vroom ${ }^{3}$, M G Nieuwenhuis ${ }^{1}$, M A Blankenstein ${ }^{2}$, C J M Lips ${ }^{1}$, \\ $\mathrm{J}^{\mathrm{A}}$ Fischer $^{4}$ and J W M Höppener ${ }^{1,3}$ \\ Departments of ${ }^{1}$ Internal Medicine, ${ }^{2}$ Endocrinology and ${ }^{3}$ Pathology, University Hospital Utrecht, PO Box 85500, 3508 GA Utrecht, \\ The Netherlands and ${ }^{4}$ Research Laboratory for Calcium Metabolism, Departments of Orthopedic Surgery and Medicine, University of Zürich, \\ Forchstrasse 340, CH-8008, Zürich, Switzerland
}

(Correspondence should be addressed to J W M Höppener, University Hospital Utrecht, H 04.313, Department of Pathology. PO Box 85500, 3508 GA Utrecht, The Netherlands)

\begin{abstract}
Objective: Islet amyloid polypeptide (IAPP), also named amylin, is the predominant protein component of amyloid deposits in human islet $\beta$ cell tumours of the pancreas (insulinomas). IAPP is co-produced with insulin by islet $\beta$ cells. We investigated IAPP expression in relation to insulin expression and to amyloid formation in eleven insulinomas.

Design and methods: RNA and protein extracts were prepared from the same pieces of tumour tissue, and from specimens of two normal human pancreata. IAPP and insulin mRNA and peptide content were quantified using Northern blot analysis and radioimmunoassay (RIA) respectively. Molecular forms of IAPP immunoreactivity were analysed by reversed-phase high-performance liquid chromatography (HPLC). The presence of islet hormones and of amyloid was assessed by (immuno)histochemical staining of paraffin sections. Plasma levels of IAPP and insulin prior to tumour resection were determined by RIA.

Results: IAPP and insulin mRNA and peptide content varied widely between the tumour specimens, and there was considerable intratumour heterogeneity of peptide content. HPLC analysis indicated correct proteolytic processing of the IAPP precursor protein. Amyloid deposits were detected only in the three tumours with the highest IAPP content. In contrast to insulin, plasma levels of IAPP were not elevated in the insulinoma patients.

Conclusions: The spectrum of hormone production by insulinomas cannot be inferred from only a few tissue sections due to intratumour heterogeneity. Expression of the IAPP and insulin genes is not coupled in insulinomas, which produce properly processed mature IAPP. In addition to IAPP overproduction, additional factors such as intracellular accumulation of IAPP are involved in amyloidogenesis in insulinomas.
\end{abstract}

European Journal of Endocrinology 140 69-78

\section{Introduction}

Insulinoma is the most common pancreatic endocrine tumour, with an estimated annual incidence of four cases per million (1). In over $50 \%$ of insulinomas investigated, amyloid deposits have been demonstrated (2-4). The major protein component of these deposits was identified as islet amyloid polypeptide (IAPP) $(5,6)$. A peptide with the same amino acid (aa) sequence was purified from pancreatic islet amyloid in patients with type 2 (non-insulin-dependent) diabetes mellitus (7) and was named amylin (8).

Islet amyloid polypeptide is a 37 aa polypeptide, which has $43 \%$ and $46 \%$ aa sequence identity with calcitonin gene-related peptide-I and -II respectively (9). IAPP is produced in islet $\beta$ cells and co-secreted with insulin in response to glucose and other $\beta$ cell secretagogues $(10,11)$. Human IAPP is synthesized as part of an 89 aa precursor protein (preproIAPP) which includes a 22 aa amino-terminal signal peptide for transport through the endoplasmic reticulum $(12,13)$. Proteolytic cleavage of the 67 aa propeptide (pIAPP) at pairs of basic aa residues yields mature IAPP(1-37), as well as amino- and carboxy-terminal flanking peptides (N-pIAPP of 9 aa and C-pIAPP of 16 aa respectively) (Fig. 1).

Several potential physiological functions of IAPP have been reported which include inhibition of insulin secretion from $\beta$ cells and inhibition of actions of insulin on glucose metabolism (14). 


\section{Met Gly Ile Leu Lys Leu Gln Val Phe Leu Ile Val Leu Ser Val Ala Leu Asn His Leu Lys Ala Thr Pro Ile Glu Ser His Gln Val Glu Lys Arg Lys Cys Asn Thr Ala Thr Cys Ala Thr Gln Arg Leu Ala Asn Phe Leu Val His Ser Ser Asn Asn Phe Gly Ala Ile Leu Ser Ser Thr Asn Val Gly Ser Asn Thr Tyr Gly Lys Arg Asn Ala Val Glu Val Leu Lys Arg Glu Pro Leu Asn Tyr Leu Pro Leu}

Figure 1 Amino acid (aa) sequence of the 89 aa precursor protein of human islet amyloid polypeptide (preprolAPP). The sequence of IAPP (1-37) is given in italic bold type and the amino- and carboxy-terminal flanking peptides of 9 and 16 aa (N-pIAPP and C-pIAPP) are underlined.

The purpose of the present study was to examine relationships between IAPP and insulin expression and their relations with the presence of amyloid deposits in endocrine pancreatic tumours clinically diagnosed as insulinomas. Expression was studied at the immunohistochemical, mRNA and peptide level and molecular form(s) of IAPP were characterized using reversedphase high-performance liquid chromatography (HPLC).

\section{Materials and methods}

\section{Tissues}

Two normal human pancreas specimens were obtained at autopsy, and served as a reference for protein levels in non-tumour pancreas tissue, as well as a positive control for the immunohistochemical detection of islet hormones and endocrine markers. Pancreatic neoplasms were from eleven patients operated on between 1986 and 1994. One patient (patient a) suffered from multiple endocrine neoplasia type 1 (MEN 1), and one patient (patient $\mathrm{k}$ ) had a malignant islet cell tumour with liver metastases.

Samples of each tumour were snap frozen in liquid nitrogen immediately after surgical resection and stored at $-80{ }^{\circ} \mathrm{C}$ until use. Parallel samples were fixed in buffered formalin for 24 to $48 \mathrm{~h}$ and embedded in paraffin.

\section{Histopathology and immunohistochemistry}

Besides haematoxylin and eosin staining, Congo red (CR) staining of tumour sections was performed for the detection of amyloid deposits (15). These CR-stained sections were examined by polarized light microscopy, which reveals an apple-green birefringence of amyloid deposits, and by UV light microscopy, visualizing autofluorescent CR-stained material.

Immunohistochemical staining on paraffin sections was performed as described (16). The presence of chromogranin, glucagon, gastrin, Ki 67 antigen, insulin and IAPP was determined with the antibodies listed in Table 1, and semiquantitatively scored from 0

Table 1 Antibodies used in immunohistochemistry.

\begin{tabular}{|c|c|c|c|c|}
\hline Antibody & Specificity & $\begin{array}{l}\text { Clone or } \\
\text { code no. }\end{array}$ & Dilution & Source \\
\hline \multicolumn{5}{|l|}{ Monoclonal } \\
\hline Anti Ki 67 & $\begin{array}{l}345 \text { and } 395 \mathrm{kDa} \text { nuclear antigen of } \\
\text { proliferating cells (G1, S, G2, M phases) }\end{array}$ & MIB-1 & $2 \mu \mathrm{g} / \mathrm{ml}$ & Immunotech, Marseille, France \\
\hline \multicolumn{5}{|l|}{ Polyclonal } \\
\hline Rabbit anti-chromogranin A & C-terminal region of chromogranin $\mathrm{A}$ & A430 & $1: 500$ & DAKO, Glostrup, Denmark \\
\hline Rabbit anti-glucagon & Porcine/human glucagon & A565 & $1: 1000$ & DAKO, Glostrup, Denmark \\
\hline Rabbit anti-gastrin & $\begin{array}{l}\text { Non-sulphated I and sulphated II forms } \\
\text { of gastrin-17 and -34 }\end{array}$ & A568 & $1: 2000$ & DAKO, Glostrup, Denmark \\
\hline Guinea pig anti-insulin & Porcine/human insulin & A 564 & $1: 1000$ & DAKO, Glostrup, Denmark \\
\hline Rabbit anti-IAPP & As described & K1338 & $1: 800$ & van Hulst et al. (22) \\
\hline
\end{tabular}


(negative) to $1-5 \%, 6-10 \%, \quad 11-25 \%, \quad 26-50 \%$, $51-75 \%$ or $76-100 \%$, indicating the percentage of positive tumour cells in a representative region of the stained tissue section analysed.

\section{Tissue and plasma extraction}

Tissue was powdered in liquid nitrogen and two portions were separated for extraction of total cellular RNA (17) and polypeptides respectively. The latter were extracted overnight in acidified ethanol, lyophilized and prepared for radioimmunoassay (RIA) (18). The DNA content in tissue pellets was measured (19) as a reference for peptide quantification in the tissue extracts. For the determination of IAPP levels in the circulation, EDTA-plasma of insulinoma patients was extracted with acid-acetone (11).

\section{Northern blot analysis}

Samples of $20 \mu \mathrm{g}$ total cellular RNA were analysed by Northern blotting as described (13). A 588 base pairs human IAPP probe and a 751 base pairs human insulin probe were described previously (20). An 18S ribosomal RNA (rRNA) probe was provided by GW M Swart (Department of Biochemistry, University of Nijmegen, The Netherlands). The probes were labelled with $\left[\alpha_{-}{ }^{32} \mathrm{P}\right] \mathrm{dCTP}$ (Amersham, Little Chalfont, Bucks, UK) using a Prime-a-Gene labelling system (Promega Corporation, Madison, WI, USA). Hybridization conditions were described previously (21). For quantitation of mRNA, IAPP and insulin probes were dot-blotted in increasing amounts of $1,5,10,50,100,500,1000$ and $5000 \mathrm{pg}$ and hybridized together with the Northern blots. Quantitation of hybridization signals was performed by phosphor-imaging and ImageQuant version 3.3 software (Molecular Dynamics, Inc. GmbH, Krefeld, Germany). To correct for different amounts of RNA loaded on the gel, hybridization signals were normalized to the $18 \mathrm{~S}$ rRNA hybridization signal.

\section{Reversed-phase high-performance liquid chromatography}

Tissue extracts were subjected to reversed-phase HPLC on a Nucleosil 100-7C18 column (Machery-Nagel, Düren, Germany) as described previously (18). Mean recoveries of synthetic human IAPP and C-pIAPP were $87.5 \pm 9.1 \%(n=4)$ and $91.2 \pm 2.9 \% \quad(n=2)$ respectively.

\section{Radioimmunoassays}

Immunoreactive IAPP and insulin were measured by RIA as described (11). For the IAPP RIA, IAPP antiserum K1338 to human IAPP was used (22). In normal subjects, plasma levels of IAPP ranged from non-detectable $(<1.1 \mathrm{pmol} / \mathrm{l})$ to $14 \mathrm{pmol} / \mathrm{l}(11)$.

Immunoreactive C-pIAPP was determined by RIA using antiserum K1352 (20, 22). This antiserum was obtained by subcutaneous injection of a New Zealand white rabbit with $35 \mu \mathrm{g}$ synthetic C-pIAPP (preproIAPP (74-89); Peninsula Laboratories, Belmont, CA, USA) conjugated to bovine thyroglobulin (Sigma, St Louis, MO, USA) using 1\% glutaraldehyde. Booster injections were administered every three weeks. The antiserum collected after the 11th injection was used at a final dilution of 1:250 000. Antibody-bound and free radioligands were separated using donkey anti-rabbit coated cellulose (IDS, Boldon, UK) as antibody-immunoprecipitating reagent. The detection limit of the RIA $\left(\mathrm{B}_{0}-2 \mathrm{SD}\right)$ was $0.30 \pm 0.14 \mathrm{fmol} /$ tube $(n=6)$.

\section{Statistical analysis}

Results were calculated as means \pm SD. Relationships between IAPP and insulin mRNAs and their corresponding peptides were analysed using Pearson's correlation coefficient, and $P$ values $<0.05$ were considered statistically significant.

\section{Results}

\section{Patients, histopathology and immunohistochemistry}

Clinical characteristics and preoperative plasma levels of immunoreactive IAPP and insulin are depicted in Table 2. In most patients plasma levels of insulin were elevated, but those of IAPP did not differ from healthy subjects.

All tumours analysed had features of islet cell tumours. Ten tumours were benign (islet cell adenoma), whereas the tumour of patient $\mathrm{k}$ appeared to be malignant (islet cell carcinoma) because of the occurrence of liver metastases. The diameter of the tumours ranged from 1 to $9 \mathrm{~cm}$ (Table 3).

Immunohistochemical analysis of the majority of tumour specimens was performed in detail (Table 3, Fig. 2). Insulin was detected in a low percentage of tumour cells in eight of the ten specimens investigated. Eight of the eleven tumours stained for IAPP and the percentage of positive cells ranged from 5 to $100 \%$. IAPP producing tumour cells were found as foci in the tumour of patient $i$ and only in the peripheral area of the tumour in patient $\mathrm{j}$. In the tumour sections of all the other patients IAPP producing cells were evenly distributed. In some tumours, IAPP was also demonstrated in connective tissue stroma. These IAPP immunoreactive structures were identified as amyloid deposits (Figs 2 and 3). All of the ten specimens investigated stained for chromogranin. Two of the ten tumours stained for glucagon, albeit in a low 


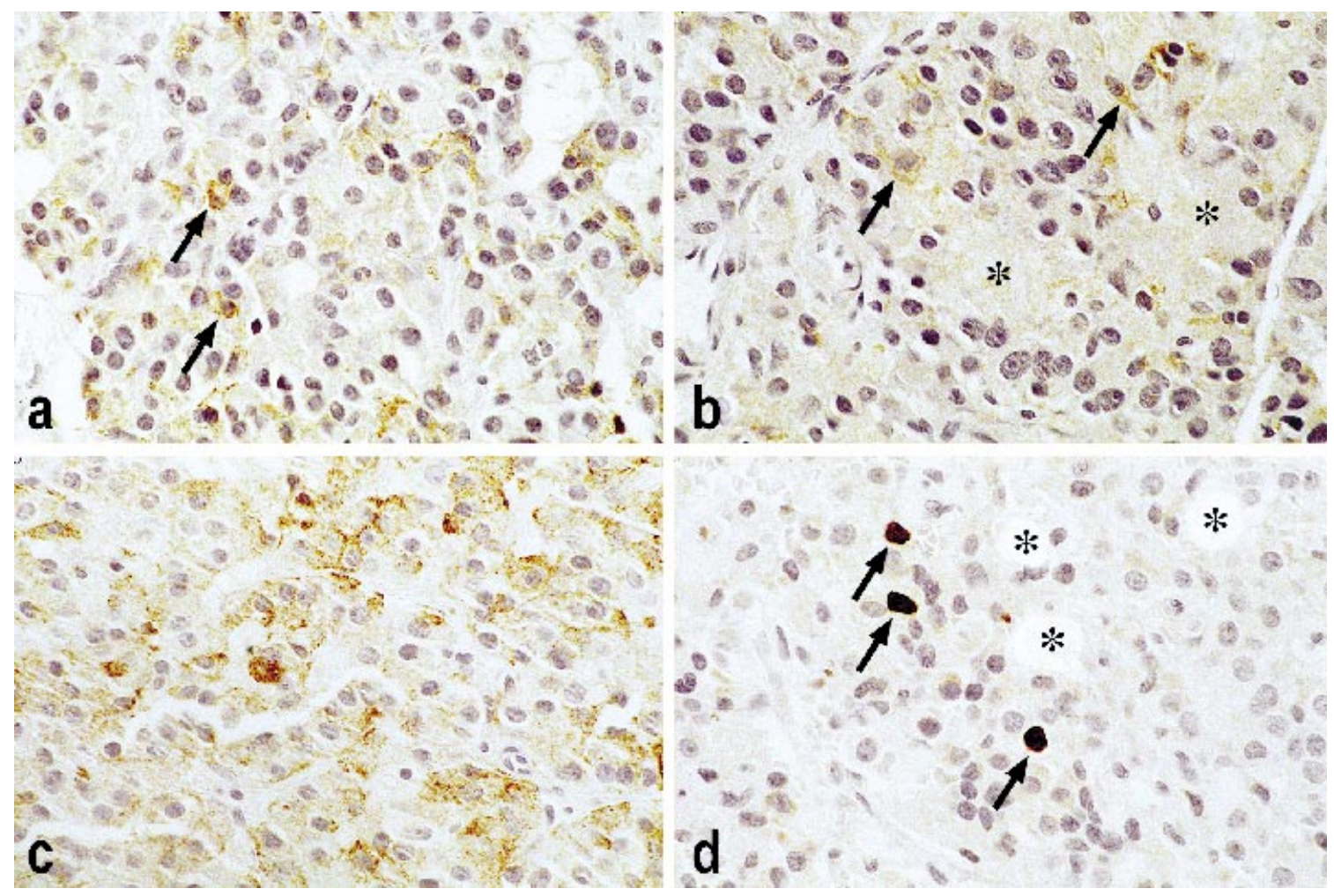

Figure 2 Paraffin sections of insulinoma tissue from patient $\mathrm{c}$ stained with antibodies to (a) insulin, (b) IAPP, (c) chromogranin A, and (d) Ki 67 nuclear antigen. In panels (a) and (b), arrows indicate moderately immunoreactive cells lying between numerous weakly immunoreactive or negative tumour cells. Amyloid deposits $\left(^{*}\right)$ are weakly IAPP-immunoreactive. In panel (c), many tumour cells are stained for chromogranin A, in accordance with the endocrine nature of the tumour. In panel (d), the nuclei of three tumour cells are Ki 67-immunoreactive (arrows), whereas amyloid deposits $\left({ }^{*}\right)$ are negative with this antibody. (Magnification: 150-fold).

percentage of cells, and six of the ten tumours investigated stained for gastrin. In general the number of cell divisions, as determined with $\mathrm{Ki} 67$ antigen antibody, was small, except for the islet cell carcinoma from patient $\mathrm{k}$.

Tumours from patients a, b and c showed hyalinization of connective tissue stroma with Congo red-positive fibrillar material deposits. Congo red autofluorescence revealed fine needle-like structures located within or between tumour cells and apparently confluent into the amyloid deposits (Fig. 3).

\section{Analysis of insulinoma extracts}

Northern blot analysis of insulinoma RNAs revealed a large variation of IAPP and, to a lesser extent, of insulin gene expression (Fig. 4). The ratio between IAPP and insulin mRNA content ranged from 0.01 to 5.29 (Table 4).

Concentrations of immunoreactive IAPP and insulin in extracts of specimens of two normal human pancreata were 22.2 and 26.4 fmoleq IAPP/ $\mu$ g DNA and 0.7 and $4.7 \mathrm{pmoleq}$ insulin $/ \mu \mathrm{g}$ DNA respectively. In the insulinoma tissue extracts both immuno- reactive IAPP and insulin varied substantially, their ratio ranging from $0.004 \%$ to $78.8 \%$ (Table 4). A statistically significant correlation was detected between mRNA and peptide levels of IAPP $(r=0.70$, $P<0.02$ ), whereas no correlation was found between mRNA and peptide levels of insulin. Ratios between IAPP and insulin mRNA only revealed a statistically significant correlation with the corresponding peptide ratios when insulinoma patient $\mathrm{c}$ (see below) was omitted from the calculation $(r=0.72, P<0.02)$. In five tumours immunoreactive C-pIAPP was detected next to IAPP. In these tumours, levels of C-pIAPP revealed a statistically significant correlation with those of IAPP $(r=0.91, P<0.04)$. An exceptional case was the insulinoma of patient $\mathrm{c}$, in which no immunoreactive C-pIAPP was detected, despite a high IAPP content. In this tumour, the low IAPP mRNA level was also not in agreement with the high IAPP peptide level. Insulinoma extracts from patients a to f, as well as a normal human pancreas extract, were analysed by reversed-phase HPLC to examine the molecular form(s) of immunoreactive IAPP and C-pIAPP in these tissues. In all extracts, the majority of immunoreactive IAPP (ranging from 50.1 to $84.5 \%$ ) 

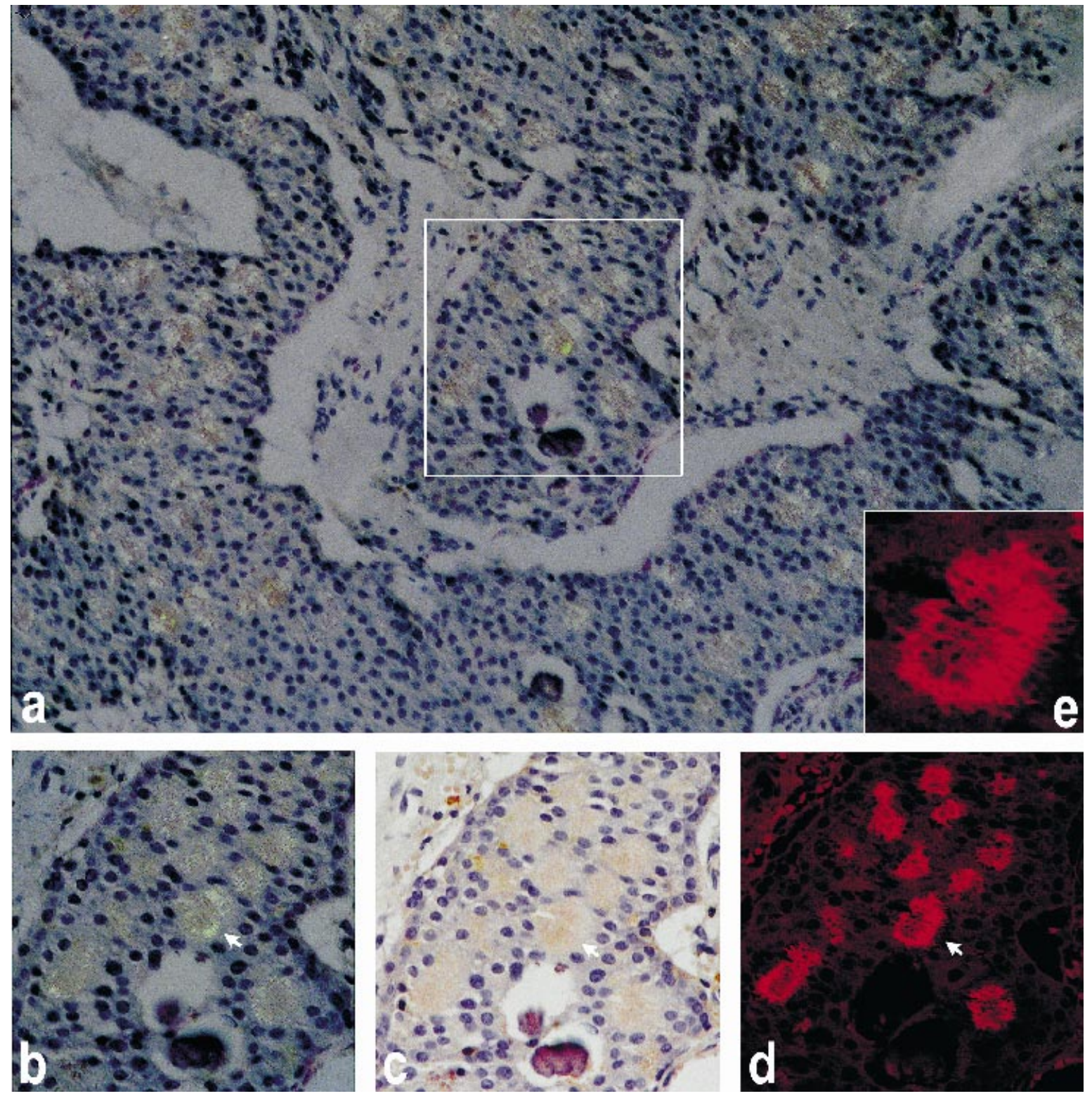

Figure 3 Paraffin section of insulinoma tissue from patient a stained with Congo red. (a) Low magnification (50-fold) shows tumour cells around stroma focally birefringent under polarized light. (b) Higher magnification (150-fold) of the marked central area in (a) shows small patches of green birefringence of the amyloid under polarized light. The same area as in (b) is shown in (c) under ordinary light, and in (d) under UV-light. (e) Higher magnification (450-fold) of (d) shows fine fluorescent needles protruding from or situated in tumour cells and apparently confluent into the Congo red positive stroma.

and of immunoreactive C-pIAPP (ranging from 87.4 to $100 \%$ ) had the retention time of synthetic amidated IAPP(1-37) and C-pIAPP respectively (Fig. 5). Two smaller peaks of immunoreactive IAPP (around fractions 30 and 36 respectively) were observed both in the normal human pancreas and in 5 of the 6 insulinomas. The smaller peak of immunoreactive IAPP around fraction 30 co-eluted with immunoreactive C-pIAPP. In the insulinoma extract of patient a, small peaks of immunoreactive IAPP and C-pIAPP were detected around fraction 70. Another peak of immunoreactive IAPP (around fraction 47) was only detected in insulinoma tissue extracts of patients a, c, e and f.

\section{Discussion}

\section{Immunohistochemistry}

Immunohistochemical analysis confirmed that all tumours investigated originated from the endocrine 
Table 2 Sex, age and fasting plasma levels of IAPP and insulin (determined prior to surgery) of insulinoma patients.

\begin{tabular}{lcccc}
\hline Insulinoma patient & $\begin{array}{c}\text { Sex } \\
(\mathrm{M} / \mathrm{F})\end{array}$ & $\begin{array}{c}\text { Age } \\
\text { (years) }\end{array}$ & $\begin{array}{c}\text { IAPP } \\
\text { (pmoleq/l) }\end{array}$ & $\begin{array}{c}\text { Insulin } \\
\text { (pmoleq/l) }\end{array}$ \\
\hline $\mathrm{a}^{*}$ & $\mathrm{M}$ & 17 & 10.6 & $\mathrm{ND}$ \\
$\mathrm{b}$ & $\mathrm{F}$ & 42 & 9.3 & 154 \\
$\mathrm{C}$ & $\mathrm{F}$ & 66 & 5.5 & 88 \\
$\mathrm{~d}$ & $\mathrm{~F}$ & 80 & 10.5 & 176 \\
$\mathrm{e}$ & $\mathrm{F}$ & 26 & 9.6 & 213 \\
$\mathrm{f}$ & $\mathrm{M}$ & 46 & 10 & 176 \\
$\mathrm{~g}$ & $\mathrm{M}$ & 21 & 8.4 & 51 \\
$\mathrm{~h}$ & $\mathrm{M}$ & 43 & $<2$ & 418 \\
$\mathrm{i}$ & $\mathrm{F}$ & 67 & 6.7 & 1356 \\
$\mathrm{j}$ & $\mathrm{M}$ & 33 & 1.7 & 139 \\
$\mathrm{k}$ & $\mathrm{M}$ & 51 & 8.6 & 572 \\
Upper limit of plasma levels & & & & \\
in normal subjects & & & 14 & 110 \\
\hline
\end{tabular}

* Patient with MEN 1; ND = not done.

pancreas. Several islet hormones were demonstrated, with a considerable inter- and intra-tumour variation in the number and distribution of cells producing these hormones. Focal localization of IAPP and insulin producing cells in the tumours of patients a and $\mathrm{g}$, or insufficient sensitivity of IAPP and insulin immunohistochemistry, may explain the absence of IAPP and insulin staining cells in selected tissue sections, in the face of detectable amounts of both peptides in extracts of tissue specimens of the same tumours. Alternatively, or in addition, secreted peptides present in blood vessels may contribute to the levels of immunoreactive peptides measured in extracts, whereas immunohistochemistry detects the cellular peptides.

\section{Analysis of insulinoma extracts}

Messenger RNA and peptide levels of IAPP and insulin, as well as ratios between IAPP and insulin, both at the
mRNA and peptide level, showed enormous variation between the tumour specimens. This supports the notion that the expression of the two genes is not necessarily coupled (23-25). Levels of immunoreactive IAPP and insulin were elevated in about $50 \%$ of insulinoma specimens, as compared with the normal human pancreas. A correlation was found between mRNA and peptide levels of IAPP, but not of insulin. Uncontrolled insulin release, also through a constitutive pathway, and/or decreased storage capacity for insulin in tumour cells may account for this difference (26).

O'Brien et al. (24) postulated distinct populations of islet $\beta$ cells that contain different relative amounts of IAPP and insulin, and Pipeleers (27) reported functionally heterogeneous $\beta$ cell populations in the human pancreas. Large differences in ratios between IAPP and insulin in the insulinoma specimens investigated in this study indicate that these tumours may have originated from different types of $\beta$ cells.

Table 3 Histopathology and immunohistochemistry of the insulinomas investigated.

\begin{tabular}{|c|c|c|c|c|c|c|c|c|c|}
\hline $\begin{array}{l}\text { Insulinoma } \\
\text { patient }\end{array}$ & $\begin{array}{l}\text { Diameter of } \\
\text { tumour(s) } \\
(\mathrm{cm})\end{array}$ & Insulin ${ }^{a}$ & IAPP $^{a}$ & Chromogranin $^{a}$ & Glucagon $^{a}$ & Gastrin $^{\mathrm{a}}$ & $\begin{array}{l}\mathrm{Ki} 67^{\mathrm{a}} \\
\text { antigen }\end{array}$ & $\begin{array}{l}\text { Hyalinization } \\
(+/-)\end{array}$ & $\begin{array}{c}\text { Congo red } \\
(+/-)\end{array}$ \\
\hline a & 3 & 0 & 0 & $+^{b}$ & 0 & $+^{b}$ & ND & + & + \\
\hline$b$ & 2 & $+^{b}$ & $51-75$ & ND & ND & ND & ND & + & + \\
\hline C & 1 & $6-10$ & $11-25$ & $76-100$ & 0 & $6-10$ & $1-5$ & + & + \\
\hline$d$ & 1.1 & $6-10$ & $76-100$ & $76-100$ & 0 & 0 & $1-5$ & - & - \\
\hline e & 2 & $1-5$ & $6-10$ & $76-100$ & $1-5$ & $11-25$ & $6-10$ & - & - \\
\hline$f$ & 1.3 & $6-10$ & $76-100$ & $51-75$ & 0 & $1-5$ & $1-5$ & - & - \\
\hline$g$ & 4 & 0 & 0 & $76-100$ & 0 & 0 & $1-5$ & - & - \\
\hline $\mathrm{h}$ & 1.5 & $6-10$ & $6-10$ & $76-100$ & 0 & 0 & $1-5$ & - & - \\
\hline $\mathrm{i}$ & 9 & $6-10$ & $6-10$ & $76-100$ & $6-10$ & $6-10$ & $1-5$ & - & - \\
\hline j & 3 & $1-5$ & $76-100$ & $76-100$ & 0 & 0 & $1-5$ & - & - \\
\hline k & ND & $6-10$ & 0 & $76-100$ & 0 & $6-10$ & $11-25$ & - & - \\
\hline
\end{tabular}

\footnotetext{
a Percentage of stained cells; ${ }^{b}$ Percentage of immunoreactive cells not determined; ND = not done.
} 


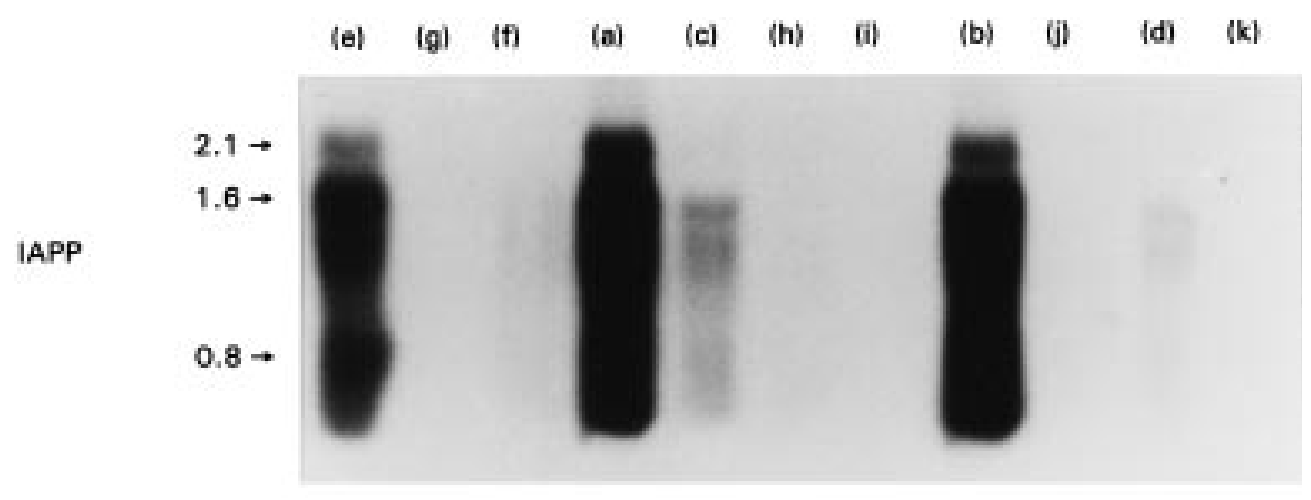

insulin

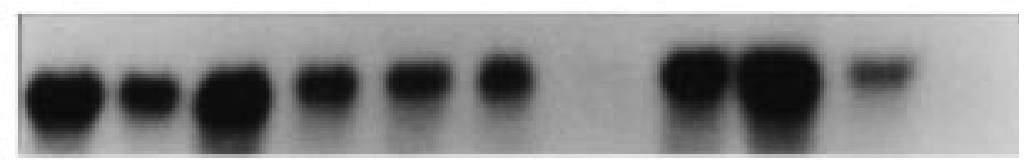

185

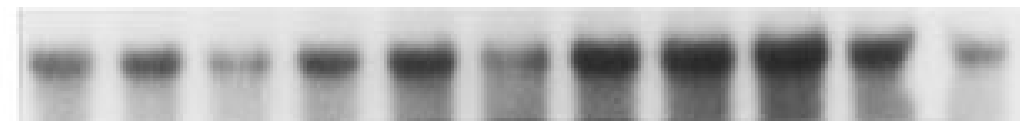

Figure 4 Northern blot analysis of total cellular RNA $(20 \mu \mathrm{g})$ from insulinoma specimens of patients a to $\mathrm{k}$. Northern blots were consecutively hybridized with a human IAPP probe detecting the human IAPP mRNAs of $0.8,1.6$ and $2.1 \mathrm{~kb}(38)$ as indicated by the arrows (top panel); with a human insulin probe detecting the human insulin mRNA of approximately $0.7 \mathrm{~kb}$ (39) (middle panel); and with an 18S rRNA probe (bottom panel). Dot-blots of unlabelled human IAPP and human insulin probes were used to quantitate mRNA hybridization signals, which were subsequently normalized to the 18S rRNA hybridization signal (see Materials and methods and Table 4).

Reversed-phase HPLC revealed that the predominant immunoreactive IAPP and C-pIAPP components in insulinoma tissue extracts had the retention times of the corresponding synthetic peptides, indicating proper processing of preproIAPP in $\beta$ cell tumours. Minor components, some of which may contain both IAPP and C-pIAPP immunoreactivity, were detected in some tumour extracts and may correspond to aberrant or partial proteolytic processing products of preproIAPP. The presence of mature $\operatorname{IAPP}(1-37)$ as the major immunoreactive IAPP component in insulinomas was also reported by Bretherton-Watt et al. (28), using gel permeation chromatography.

\section{Plasma IAPP and insulin levels}

In insulinoma patients the plasma levels of IAPP, in contrast to those of insulin, were within the normal range. Stridsberg et al. (29) detected an elevated plasma level of IAPP in only 1 of 11 insulinoma

Table 4 Ratio between concentrations of IAPP and insulin mRNAs, concentrations of insulin, IAPP, and its C-terminal flanking peptide (C-pIAPP), and the ratio between IAPP and insulin in insulinoma tissue extracts.

\begin{tabular}{|c|c|c|c|c|c|}
\hline $\begin{array}{l}\text { Insulinoma } \\
\text { patient }\end{array}$ & $\begin{array}{l}\text { IAPP/insulin } \\
\text { mRNA ratio }\end{array}$ & $\begin{array}{c}\text { IAPP } \\
(\text { fmoleq } / \mu \mathrm{g} \text { DNA })\end{array}$ & $\begin{array}{c}\text { Insulin } \\
(p m o l e q / \mu \mathrm{g} D N A)\end{array}$ & $\begin{array}{l}\text { IAPP/insulin } \\
\text { peptide ratio } \\
\quad\left(\times 10^{-2}\right)\end{array}$ & $\begin{array}{c}\text { C-plAPP } \\
(\text { fmoleq } / \mu \mathrm{g} \text { DNA })\end{array}$ \\
\hline a & 5.29 & 523.3 & 9.4 & 5.6 & 128.8 \\
\hline $\mathrm{b}$ & 1.60 & 438.8 & 49.5 & 0.9 & 51.1 \\
\hline c & 0.43 & 551.4 & 0.7 & 78.8 & $<2.7$ \\
\hline d & 0.20 & 80.7 & 7.8 & 1.0 & 3.5 \\
\hline e & 1.21 & 54.2 & 2.0 & 2.7 & 14.7 \\
\hline$f$ & 0.11 & 52.2 & 26.4 & 0.2 & 4.4 \\
\hline g & 0.03 & 2.4 & 53.8 & 0.004 & $<1.4$ \\
\hline $\mathrm{h}$ & 0.17 & 13.3 & 2.1 & 0.6 & $<1.3$ \\
\hline i & 0.39 & $<2.1$ & 0.6 & $<0.4$ & $<1.4$ \\
\hline j & 0.01 & $<3.0$ & 12.9 & $<0.02$ & $<2.0$ \\
\hline $\mathrm{k}$ & 0.10 & $<4.6$ & 0.1 & $<4.6$ & $<2.3$ \\
\hline \multicolumn{2}{|c|}{ Normal pancreas $(n=2)$} & $22.2,26.4$ & $0.7,4.7$ & $3.17,0.56$ & $1.0,<1.0$ \\
\hline
\end{tabular}



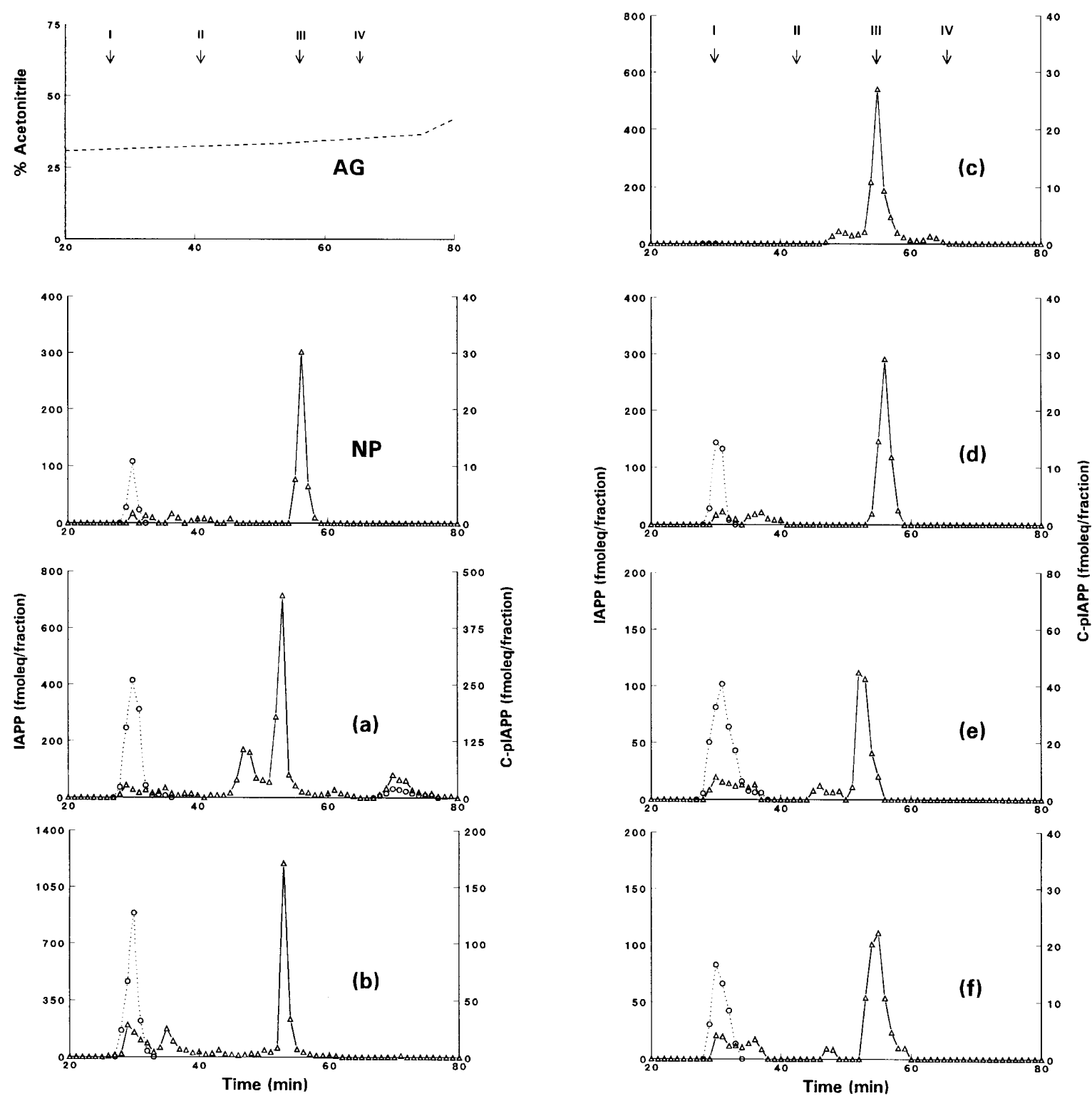

Figure 5 Reversed-phase HPLC profiles of extracts from a normal human pancreas (NP) and six insulinomas (a to f). Individual fractions were analysed for immunoreactive IAPP $(\triangle)$ and C-pIAPP $(O)$. The acetonitrile gradient (AG) is represented by the dotted line and arrows indicate the retention times of synthetic human C-pIAPP (I) and IAPP(1-37) (III), as well as of ${ }^{125}$-human calcitonin gene-related peptide I (II) and ${ }^{125}$ I-salmon calcitonin (IV).

patients investigated. The concentrations of these peptides in plasma may not reflect those in insulinoma extracts, because of cellular heterogeneity and different sizes of the tumours. Nevertheless, normal plasma levels of IAPP, in the presence of increased tumour IAPP content, suggests retention of IAPP by the tumour tissue.

\section{IAPP expression in relation to amyloidogenesis}

The highest concentrations of immunoreactive IAPP were revealed in insulinoma specimens of patients $a, b$ and c. The high IAPP mRNA content in the insulinomas of patients $a$ and $b$ indicate overproduction of IAPP. In insulinoma tissue of patient c, however, high IAPP concentrations were associated with low IAPP mRNA content and with undetectable immunoreactive C-pIAPP. Remarkably, amyloid deposits were only detected in tumours of patients a, b and c, suggesting that amyloid deposition is associated with high local concentrations of IAPP. This agrees with a report by Tasaka et al. (30), demonstrating that also in patients with type-2 diabetes mellitus, amyloid deposition in 
pancreatic islets was associated with a high pancreatic IAPP content. The discrepancy between IAPP mRNA and peptide contents in the insulinoma extract of patient $\mathrm{c}$ may be due to excessive intracellular accumulation of the peptide, inducing amyloid formation despite a low production. Thus, besides IAPP overproduction additional factors, such as increased cellular retention of IAPP, may be essential for amyloidogenesis in pancreatic tissue.

Novials et al. (25) demonstrated that exposure of isolated human islets to high glucose concentrations resulted in enhanced IAPP synthesis but impaired IAPP secretion. In transgenic mice overexpressing human IAPP mRNA as compared with endogenous mouse IAPP mRNA (20), elevated plasma levels of IAPP (up to 15-fold) were revealed when compared with nontransgenic animals. Islet amyloid was not demonstrated in these animals by histochemical staining or electron microscopy $(20,31)$. When pancreatic islets of these human IAPP transgenic mice were cultured in high glucose medium, intra- and extracellular amyloid fibrils were formed (32), probably as a result of enhanced intracellular accumulation of IAPP. Also in other human IAPP transgenic mouse models, islet amyloid formation has been associated with hyperglycaemia, suggesting the involvement of increased intracellular IAPP concentrations (33-35). Congo red staining or birefringence are inadequate for the detection of small deposits of amyloid fibrils. The autofluorescent properties of Congo red, however, served to detect small needlelike structures by using UV-light microscopy, suggesting an intracellular origin of amyloid deposits (4).

\section{Conclusions}

The present study demonstrates independent and heterogeneous expression of IAPP and insulin in human insulinomas. Therefore, immunohistochemical analysis of a few tissue sections does not necessarily reflect the concentrations of these peptides in different pieces of the same tumour.

HPLC analysis of tissue extracts revealed correct proteolytic processing of the IAPP precursor in insulinomas. In these islet $\beta$ cell tumours the secretion of IAPP, however, seems impaired. Hyperglycaemia has been shown to promote intracellular accumulation of IAPP in human islet $\beta$ cells (25), suggesting a defect in IAPP secretion also in patients with type-2 diabetes.

Amyloid was detected only in the three tumours with the highest IAPP content. Both in islet $\beta$ cell tumours and in type- 2 diabetes patients, impaired IAPP secretion is probabaly involved in amyloidogenesis, associated with $\beta$ cell destruction $(36,37)$.

\section{Acknowledgements}

The authors wish to thank A Versluis and H A G Boere from the Animal House of the Medical Faculty (Utrecht
University) for biotechnological assistance, D Niermans from the Department of Endocrinology (University Hospital Utrecht) for technical assistance, J G N Geertzema from the Department of Pathology (University Hospital Utrecht) for histopathological and immunohistochemical assistance, and M Verdaasdonk from the Department of Pathology (University Hospital Utrecht) for the preparation of Fig. 3 using confocal laser scan microscopy.

This work was supported by grant 92.133 from the Diabetes Fund The Netherlands to C O, and grant 31-43094.95 from the Swiss National Science Foundation to $\mathrm{J} \mathrm{A} \mathrm{F} \mathrm{and} \mathrm{W}$ B.

\section{References}

1 Service FJ, McMahon MM, O’Brien PC \& Ballard DJ. Functioning insulinoma. Incidence, recurrence, and long-term survival of patients: a 60-year study. Mayo Clinic Proceedings 199166 711-719.

2 Westermark P, Grimelius L, Polak JM, Larsson LI, van Noorden S, Wilander E \& Pearse AGE. Amyloid polypeptide hormoneproducing tumours. Laboratory Investigation 197737 212-215.

3 Clark A, Foulis AK, McLay A, Ostle LR, Browne A \& Morris JF. Formation of amyloid in insulinomas: analysis by immunohistochemistry. Journal of Endocrinology 1989123 (Suppl) Abstract 164.

4 O’Brien TD, Butler AE, Roche PC, Johnson KH \& Butler PC. Islet amyloid polypeptide in human insulinoma. Evidence for intracellular amyloidogenesis. Diabetes 199443 329-336.

5 Westermark P, Wernstedt C, Wilander E \& Sletten K. A novel peptide in the calcitonin gene-related peptide family as an amyloid fibril protein in the endocrine pancreas. Biochemical and Biophysical Research Communications 1986140 827-831.

6 Westermark P, Wernstedt C, Wilander E, Hayden DW, O'Brien TD \& Johnson KH. Amyloid fibrils in human insulinoma and islets of Langerhans in the diabetic cat are derived from a neuropeptide-like protein also present in normal islet cells. Proceedings of the National Academy of Sciences of the USA 1987 84 3881-3885.

7 Cooper GJS, Willis AC, Clark A, Turner RC, Sim RB \& Reid KBM. Purification and characterization of a peptide from amyloidrich pancreases of type 2 diabetic patients. Proceedings of the National Academy of Sciences of the USA 198784 8628-8632.

8 Cooper GJS, Leighton B, Dimitriadis GD, Parry-Billings M, Kowalchuk JM, Howland $\mathrm{K}$ et al. Amylin found in amyloid deposits in human type 2 diabetes mellitus may be a hormone that regulates glycogen metabolism in skeletal muscle. Proceedings of the National Academy of Sciences of the USA 198885 77637766.

9 Höppener JWM, Oosterwijk C, van Hulst KL, Verbeek JS, Capel PJA, de Koning EJP et al. Molecular physiology of the islet amyloid polypeptide (IAPP)/amylin gene in man, rat and transgenic mice. Journal of Cellular Biochemistry 1994 55S 39-53.

10 Kahn SE, D’Alessio DA, Schwartz MW, Fujimoto WY, Ensinck JW, Taborsky GJ \& Porte D. Evidence of cosecretion of islet amyloid polypeptide and insulin by $\beta$ cells. Diabetes $199039634-638$.

11 van Hulst KL, Hackeng WHL, Höppener JWM, van Jaarsveld BC, Nieuwenhuis MG, Blankenstein MA \& Lips CJM. An improved method for the determination of islet amyloid polypeptide levels in plasma. Annals of Clinical Biochemistry 199431 165170 .

12 Sanke T, Bell GI, Sample C, Rubenstein AH \& Steiner DF. An islet amyloid polypeptide is derived from an 89-amino acid precursor by proteolytic processing. Journal of Biological Chemistry 1988263 17243-17246. 
13 Mosselman S, Höppener JWM, Lips CJM \& Jansz HS. The complete islet amyloid polypeptide precursor is encoded by two exons. FEBS Letters 1989247 154-158.

14 Cooper GJS. Amylin compared with calcitonin gene-related peptide: structure, biology, and relevance to metabolic disease. Endocrine Reviews 199415 163-201.

15 Putchler H, Sweat F \& Levine M. On the binding of Congo red by amyloid. Journal of Histochemistry and Cytochemistry 196210 355-364.

16 van der Leede B-JM, Geertzema J, Vroom ThM, Décimo D, Lutz Y, van der Saag PT \& van der Burg B. Immunohistochemical analysis of retinoic acid receptor- $\alpha$ in human breast tumours. RAR- $\alpha$ expression correlates with proliferative activity. American Journal of Pathology 1996148 1905-1914.

17 Chirgwin JM, Przybyla AE, MacDonald RJ \& Rutten WJ. Isolation of biologically active ribonucleic acid from sources enriched in ribonuclease. Biochemistry 197918 5294-5299.

18 van Hulst KL, Born W, Muff R, Oosterwijk C, Blankenstein MA, Lips CJM et al. Biologically active human islet amyloid polypeptide/amylin in transgenic mice. European Journal of Endocrinology 1997136 107-113.

19 Burton KA. A study of the conditions and mechanism of the diphenylamine reaction for the colorimetric estimation of deoxyribonucleic acid. Biochemistry 195662 315-323.

20 Höppener JWM, Verbeek JS, de Koning EJP, Oosterwijk C, van Hulst KL, Visser-Vernooy HJ et al. Chronic overproduction of islet amyloid polypeptide (IAPP)/amylin in transgenic mice: lysosoma localization of human IAPP and lack of marked hyperglycaemia or hyperinsulinaemia. Diabetologia 199336 1258-1265.

21 Church GM \& Gilbert W. Genomic sequencing. Proceedings of the National Academy of Sciences of the USA 198481 1991-1995.

22 van Hulst KL, Höppener JWM, Berends MJH, Nieuwenhuis MG, Blankenstein MA \& Lips CJM. Characterization of antibodies against human islet amyloid polypeptide (IAPP)/amylin and its C-terminal flanking peptide (C-proIAPP). European Journal of Endocrinology 1994130 (Suppl 2) 196.

23 Gedulin B, Cooper GJS \& Young AA. Amylin secretion from the perfused pancreas: dissociation from insulin and abnormal elevation in insulin-resistant diabetic rats. Biochemical and Biophysical Research Communications $199180782-789$.

24 O'Brien TD, Westermark P \& Johnson KH. Islet amyloid polypeptide and insulin secretion from isolated perfused pancreas of fed, fasted, glucose-treated, and dexamethasone-treated rats. Diabetes $1991401701-1706$.

25 Novials A, Sarri Y, Casamitjana R, Rivera F \& Gomis R. Regulation of islet amyloid polypeptide in human pancreatic islets. Diabetes $1993421514-1519$.

26 Creutzfeldt W, Creutzfeldt C, Frerichs H, Track NS \& Arnold R. Histochemistry, ultrastructure, and hormone content of human insulinomas. Hormone and Metabolic Research 1976 (Suppl 6) 7-18.

27 Pipeleers DG. Heterogeneity in pancreatic $\beta$ cell population. Diabetes $199241777-781$.

28 Bretherton-Watt D, Ghatei MA, Bloom SE, Williams S \& Bloom SR. Islet amyloid polypeptide-like immunoreactivity in human tissue and endocrine tumours. Journal of Clinical Endocrinology and Metabolism 199376 1072-1074.

29 Stridsberg M, Eriksson B, Lundqvist G, Skogseid B, Wilander E \& Öberg K. Islet amyloid polypeptide (IAPP) in patients with neuroendocrine tumours. Regulatory Peptides 199555 119131 .

30 Tasaka Y, Nakaya F, Matsumoto H, Iwamoto Y \& Omori Y. Pancreatic amylin content in human diabetic subjects and its relation to diabetes. Pancreas 199511 303-308.

31 de Koning EJP, Höppener JWM, Verbeek JS, Oosterwijk C, van Hulst KL, Baker CA et al. Human islet amyloid polypeptide accumulates at similar sites in islets of transgenic mice and humans. Diabetes 199443 640-644.

32 de Koning EJP, Morris ER, Hofhuis FMA, Posthuma G, Höppener JWM, Morris JF et al. Intra- and extracellular amyloid fibrils are formed in cultured pancreatic islets of transgenic mice expressing human islet amyloid polypeptide. Proceedings of the National Academy of Sciences of the USA 1994 $918467-8471$.

33 Verchere CB, D’Alessio DA, Palmiter RD, Weir GC, Bonner-Weir S, Baskin DG \& Kahn SE. Islet amyloid formation associated with hyperglycemia in transgenic mice with pancreatic beta cell expression of human islet amyloid polypeptide. Proceedings of the National Academy of Sciences of the USA 199693 3492-3496.

34 Janson J, Soeller WC, Roche PC, Nelson RT, Torchia AJ, Kreutter DK \& Butler PC. Spontaneous diabetes mellitus in transgenic mice expressing human islet amyloid polypeptide. Proceedings of the National Academy of Sciences of the USA 199693 $7283-7288$.

35 Soeller WC, Janson J, Hart SE, Parker JC, Oarty MD, Stevenson RW et al. Islet amyloid-associated diabetes in obese $A^{\mathrm{vy}} / \mathrm{a}$ mice expressing human islet amyloid polypeptide. Diabetes 199847 743-750.

36 de Koning EJP, Bodkin NL, Hansen BC \& Clark A. Diabetes mellitus in Macaca mulatta monkeys is characterised by islet amyloidosis and reduction in beta-cell population. Diabetologia $199336378-$ 384.

37 Oosterwijk C, Höppener JWM, van Hulst KL \& Lips CJM. Pancreatic islet amyloid formation in patients with non-insulindependent diabetes mellitus. Implication for therapeutic strategy. International Journal of Pancreatology 199518 7-14.

38 Höppener JWM, Oosterwijk C, Visser-Vernooy HJ, Lips CJM \& Jansz HS. Characterization of the human islet amyloid polypeptide/amylin gene transcripts: identification of a new polyadenylation site. Biochemical and Biophysical Research Communications 1992189 1569-1577.

39 Nieuwenhuis MG, van Mansfeld ADM, van Unnik JAM, Berends MJH \& Lips CJM. No constant relationship between islet amyloid polypeptide (IAPP) and insulin expression in insulinomas. Netherlands Journal of Medicine 199241 264-271.

Received 22 July 1998

Accepted 28 September 1998 